\title{
РОЛЬ ХЛОРИД-ИОНОВ ПРИ ОБРАЗОВАНИИ «2+1» ТРИКАРБОНИЛЬНЫХ КОМПЛЕКСОВ ТЕХНЕЦИЯ-99М
}

\author{
М.Ю. Тюпина, А.Е. Мирославов, Г.В. Сидоренко
}

АО «Радиевый институт им. В. Г. Хлопина», 194021, Россия, Санкт-Петербург, 2-й Муринский пр. 28.

DOI: 10.19163/MedChemRussia2021-2021-529

E-mail:mtupina@mail.ru

С момента открытия [99m $\mathrm{Tc}(\mathrm{CO})_{3}\left(\mathrm{H}_{2} \mathrm{O}\right)_{3}$ ] в качестве универсального прекурсора для биоконъюгации, трикарбонильное ядро технеция нашло широкое применение в исследованиях, направленных на разработку новых фармацевтических препаратов [1,2]. Несмотря на то, что большинство исследований проводится с использованием тридентантных лигандов, система лигандов «2+1» (бидентантный и монодентатный) также привлекает внимание исследователей.

Среди монодентатных лигандов для реализации «2+1» подхода (биомолекула связывается через монодентатный лиганд), лучшим выбором являются изонитрилы из-за благоприятного сочетания б-донор и п-акцепторных свойств (обеспечивающих высокую стабильность комплексов), низкой стерической потребности, хорошей кинетике комплексообразования и универсальности связывания с биомолекулами.

В качестве лигандов бидентантного типа мы изучали 2,2'-бипиридил и 1,10-фенантролин. Ранее в этой области практически не было попыток объединить лиганды дииминового и изонитрильного типов в комплексов типа «2+1» с ядром $\left[\mathrm{Tc}(\mathrm{CO})_{3}\right]$.

Ключевым вопросом этого исследования является оценка степени, с которой хлорид-ионы, неизбежно присутствующие в системе реакции при подготовки $\left[{ }^{99 \mathrm{~m}} \mathrm{Tc}(\mathrm{CO})_{3}\right]$ и в физиологическом растворе, вмешиваются в образование комплексов «2+1» с ядром $\left[{ }^{99 \mathrm{~m}} \mathrm{Tc}(\mathrm{CO})_{3}\right]$ и дииминовым лигандом. «2+1» трикарбонильные комплексы технеция (I) и рения (I) с дииминовыми $\mathrm{N}, \mathrm{N}$-бидентантными лиганды и этил изоцианоацетатом были синтезированы и охарактеризованы рентгеноструктурным анализом, ИК, УФ-Вид, люминесценцией, ЯМР спектроскопий, а также ВЭЖХ.

Таким образом, нами изучено конкурирующее влияние хлорид-иона при синтезе «2+1» трикарбонильных комплексов технеция и рения и установлено его существенное влияние для комплексов на основе технеция-99m,99.

\section{Литература}

[1] R. Alberto, R. Schibli, A. Egli, A.P. Schubiger, J. Am. Chem. Soc. 1998, V.120, P.7987-7988

[2] R. Alberto, K. Ortner, N.Wheatley, R.Schibli, A.P. Schubiger, J. Am. Chem. Soc. 2001, V.13, P. 3135-3136 